ZOOLOGIA 29 (6): 531-539, December, 2012

Available online at www.scielo.br/zool

\title{
Invasion process of Limnoperna fortunei (Bivalvia: Mytilidae): The case of Uruguay River and emissaries of the Esteros del Iberá Wetland, Argentina
}

\section{Gustavo Darrigran', Cristina Damborenea1, Edmundo C. Drago², Inés Ezcurra de Drago², Aldo Paira² \& Fernando Archuby ${ }^{3}$}

\author{
${ }^{1}$ CONICET, División Zoología Invertebrados, Museo de La Plata. Paseo del Bosque s/n, 1900 La Plata, Argentina. \\ 2 Instituto Nacional de Limnología; CONICET-UNL; Ciudad Universitaria, Paraje El Pozo 3000, Santa Fe, Argentina. \\ ${ }^{3}$ Facultad de Ciencias Naturales y Museo; UNLP. \\ 4 Corresponding author. E-mail: invasion@fcnym.unlp.edu.ar
}

\begin{abstract}
Limnoperna fortunei (Dunker, 1857), during its invasion process in South America, has caused severe impacts both on natural environments altering native biodiversity, ecosystem structure and function-, and on man-made structures causing economic looses. Twenty-one samples were taken from the right bank of the Uruguay River, from tributaries of the Uruguay and Paraná Rivers, the drainage of the Esteros del lbera Wetland. Based on this fieldwork, the presence of larvae and adults of $L$. fortunei was determined. Also, through the comparison of environmental characteristic with the known tolerance limits for the species, the possibility of its establishment in environments not yet invaded was determined. Most of the sampling stations have features that allow the development of stable populations $L$. fortunei, including the rivers that drain the Esteros del lbera, allowing access of this invasive species to this important wetland.
\end{abstract}

KEY WORDS. Bioinvasion; distribution; golden mussel; South America; wetland.

The invasion of Limnoperna fortunei (Dunker, 1857) or golden mussel was detected for the first time along the banks of the Río de la Plata estuary $\left(34^{\circ} 55^{\prime} \mathrm{S}, 57^{\circ} 49^{\prime} \mathrm{W}\right.$ ) in 1991(PASTORINO et al. 1993). It was introduced in ballast-water of transoceanic commercial vessels (Darrigran \& PASTORINo 1995) and invaded upstream the Plata basin at a rate of $240 \mathrm{~km}$ year ${ }^{-1}$, spreading into five South American countries (Argentina, Paraguay, Brazil, Uruguay and Bolivia) (DARRIGRAN 2010). This species of Mytilidae has become the only serious macrofouling organism in South American freshwater systems, and given that the colonies of the golden mussel could reach hundreds of thousands of individuals per square meter, the volume filtered water could severely impact freshwater environments (SYLVESTER et al. 2005, PESTANA et al. 2009). Additionally, dense populations of $L$. fortunei have a major impact on the structure of macroinvertebrate communities (DARRIGRAN et al. 1998, SARDiÑa et al. 2011). Such an environmental impact results in the golden mussel behaving as an ecosystem engineer (DARRIGRAN \& DAMBorenea 2011). Its impact may be as significant as that of the invasive zebra mussel, Dreissena polymorpha (Pallas, 1771), a Dreissenidae living in North America (Claudi \& MaCKIE 1994). L. fortunei had a rapid dispersion which can be attributed to several biological features that it shares with the zebra mussel, namely its free-swimming planktonic larval stage, a byssal filament for attachment to hard substrates, a high resistance to air exposure, and a high reproductive potential (Montalto \& Ezcurra de Drago 2003, Darrigran \& Damborenea 2005, 2006, Darrigran et al. 2007, Pestana et al. 2008).
Since it was first recorded in 1991, L. fortunei invaded the main rivers in the Plata Basin, in the following chronological order: Río de la Plata, Paraná River, Paraguay River and Uruguay River (DARRIGRAN \& MANSUR 2006). The first record in the latter was at Las Cañas, Uruguay $\left(33^{\circ} 10^{\prime} \mathrm{S}, 58^{\circ} 21^{\prime} \mathrm{W}\right)$ in 2000 , i.e., almost $10 \mathrm{y}$ after its first record in America (LANGONE 2005). In September 2001, it was detected in the reservoir at Salto Grande, about $300 \mathrm{~km}$ upstream of its junction with the Río de la Plata. This was the northernmost record along the Uruguay River until 2005 (Brugnoli et al. 2005, 2007, Langone 2005). It has since been recorded at Barra do Quarai, Brazil $\left(30^{\circ} 12^{\prime} \mathrm{S}\right.$, $57^{\circ} 33^{\prime} W$ ) (Agudo-Padrón 2008, Lima et al. 2008). Currently, the northernmost record on the Uruguay River was cited by AGUDO et al. (2012) in Barra Grande hydroelectric plant in the State of Santa Catarina, Brazil.

Since the introduction of the golden mussel in South America, the invasion pattern and dispersion velocity have been studied in order to understand the process and mechanism of this bioinvasion (Darrigran 2002, Darrigran \& Damborenea 2005, Boltovskoy et al. 2006, Darrigran et al. 2011, ZaHn et al. 2012). These studies acquire a global significance under the assumption that $L$. fortunei may eventually invade North America and Europe (Ricciardi 1998, Darrigran \& Pastorino 2004, Karatayev et al. 2007, Darrigran et al. 2007, Oliveira et al. 2010). Predictions on the potential distribution of invasive species can be made at different spatial scales of resolution (Karatayev et al. 2007). 
In the case of $L$. fortunei in South America, it is still not possible to prevent the spread of the invasion (DARRIGRAN et al. $2004,2007)$. Unfortunately, what is sought instead is only a reactive management (control) of the invasion once the invading species has settled (Darrigran \& Damborenea 2006). Studies such as that presented herein should generate the necessary basic tools for handling these biological invasions (KLUZA \& MCNyset 2005). The aim of this study was to determine the presence of $L$. fortunei along the Uruguay River system, and to assess the invasibility of those localities of the area not yet invaded, as the Iberá hydrosystem, one of the most important wetlands located south of the Tropic of Capricorn.

\section{MATERIAL AND METHODS}

The study area is known as the "Argentine Mesopotamia" because it is surrounded by the Paraná and Uruguay rivers and some of their tributaries. Despite the Argentine Mesopotamia being considered a single geographical region, it shows different geologic, geomorphologic, climatic, hydrographic and biogeographic conditions. Two climatic types dominate in this region, i.e., the Humid Subtropical of the plain and plateau to the north, and the Humid Temperate of the plain to the south (Iglesias de Cuello 1981). The average annual temperature includes the 22 and $18^{\circ} \mathrm{C}$ isotherms in the north, while in the south it is completely included between the 20 and $16^{\circ} \mathrm{C}$ isotherms (Iglesias de Cuello 1981). Average rainfall decreases from north to south, with maximums of 1,600 in the north and gradients of 1,500 to 1,100 and of 1,100 to $1,000 \mathrm{~mm}$ in the south of the Mesopotamia region (Iglesias de Cuello 1981).

The Iberá wetland - one of the largest freshwater wetlands of South America - is almost pristine (FerRaTI et al. 2005). This system is developed on fluvial sands and silts left by former channels of the Paraná River. Subsequent evolution deposited sand, silt and decomposing organic matter. Iberá is composed of shallow lakes, marshes, swamps, floating meadows (embalsados), and shallow slow-flowing streams (BonetTo \& Hurtado 1998, CasciotTa et al. 2005). Hard substrates are scarce, although floating meadows and bottom vegetation detritus are abundant (СAsCIOTA et al. 2005).

During a field trip along the Uruguay River, samples were taken from the right bank and from the center of the upper and middle main channel, between the Moconá Falls $\left(27^{\circ} 04^{\prime} \mathrm{S}\right.$, $\left.53^{\circ} 53^{\prime} \mathrm{W}\right)$ in the north and Concordia city $\left(31^{\circ} 24^{\prime} \mathrm{S}, 58^{\circ} 00^{\prime} \mathrm{W}\right)$ in the south. Also, samples were taken from the most important tributaries of the Uruguay river, such as the Miriñay (a drainage of the Iberá Swamps) and Mocoretá rivers. Additionally, samples were also obtained from tributaries of the Paraná River such as the Corriente and Santa Lucía rivers (also drainages of the Esteros del Iberá wetland), and from the largest tributary of the Corriente River, the Pay Ubre Grande brook. The middle Gualeguay river was also sampled at the city of Villaguay $\left(31^{\circ} 50^{\prime} \mathrm{S}, 59^{\circ} 00^{\prime} \mathrm{W}\right)$ (Tab. I, Fig. 1). The samples encompassed a

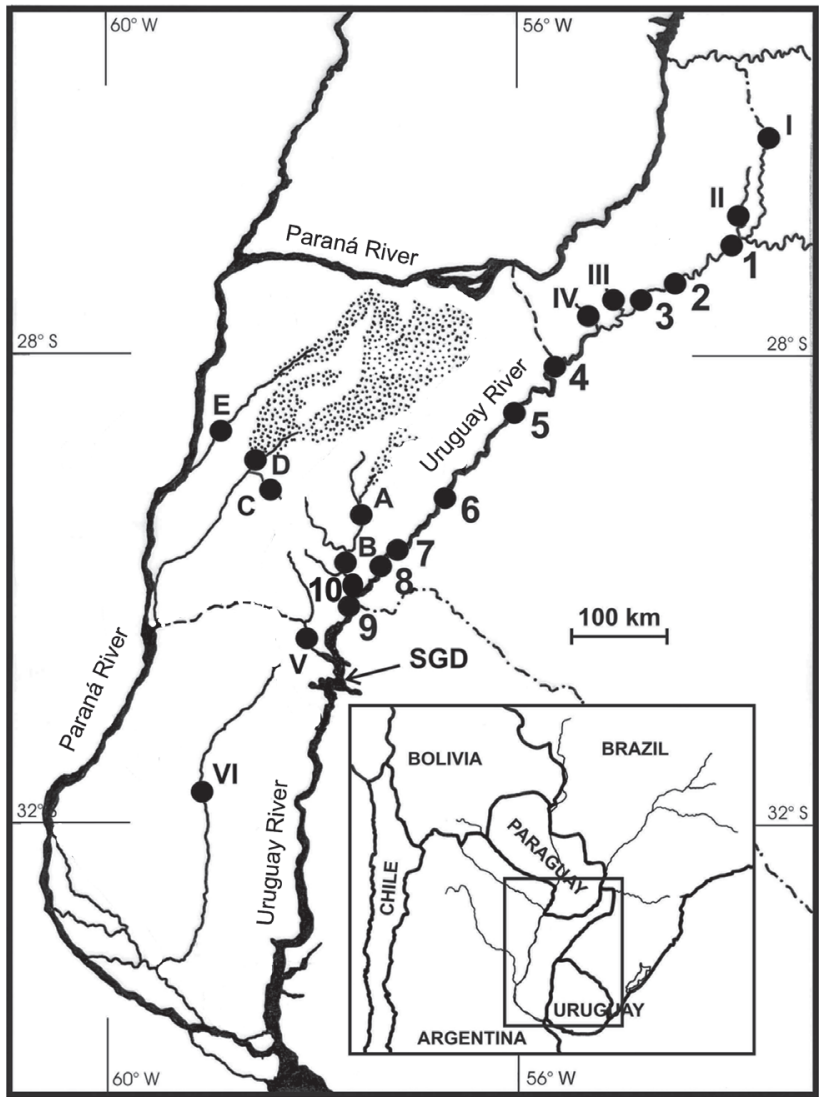

Figure 1. Sampling stations. For references see Table I. SGD, Salto Grande Dam.

total of 21 river stations during a low water period, from February $27^{\text {th }}$ to March $3^{\text {rd }} 2006$. Subsequently, field-work was carried out at the junction of the Miriñay and Uruguay Rivers in Corrientes (Argentina) during February 2007.

The presence of adult of $L$. fortunei was determined by inspecting exposed rocks, dredged-out submerged blocks and aquatic vegetation. Detection of larvae was carried out filtering $200 \mathrm{~L}$ of water in each sample station through a $35 \mu \mathrm{m}$ mesh. The larvae were recognized alive under dissection and compound microscope. The plankton samples were processed following DaRRIGRAN et al. (2007). At each sampling station (SS) the following environmental factors were recorded: water velocity, depth, water and air temperature, total dissolved salts (salinity), conductivity (water checker Hach 44600), pH, transparency (Secchi disk), suspended sediments (size less than 62 $\mathrm{mm}$ ), suspended organic matter, dissolved organic matter, dissolved oxygen, and dissolved calcium.

The environmental data were plotted in jitter plots, combined with a bar that indicates the arithmetic mean and the 95\% confidence interval, calculated with the standard error. The environmental factors were compared graphically with the 
known tolerance limits of L. fortunei (DARRIGRAN et al. 2011 and references therein).

A non-metric multi-dimensional scaling (NMDS) method was applied to analyze the relationships between the sampling stations using environmental variables. All the environmental factors mentioned above were included in the analysis, with the exception of dissolved calcium, because it was registered only in the half of the sampling stations approximately. The stress value was calculated to measure the goodness of the fit using PAST Paleontological Statistics 2.07 (HAMmer et al. 2001). The samples 10, III and IV were excluded from the analyses because not all the environmental factors were recorded.

\section{RESULTS}

Field survey of the rivers and associated aquatic habitats (Tab. I), together with measurements of the environmental variables, revealed two groups of sampling stations in the NMDS ordination (Fig. 2). One of them includes most of the sampling stations on the Uruguay River and the other includes most of the sampling stations on the emissaries of the Esteros del Iberá wetlands and tributaries of the Uruguay and Paraná rivers. The samples from Moconá Falls (SS 1) and from Yabotí River (SS II) were scored far from the other groups.

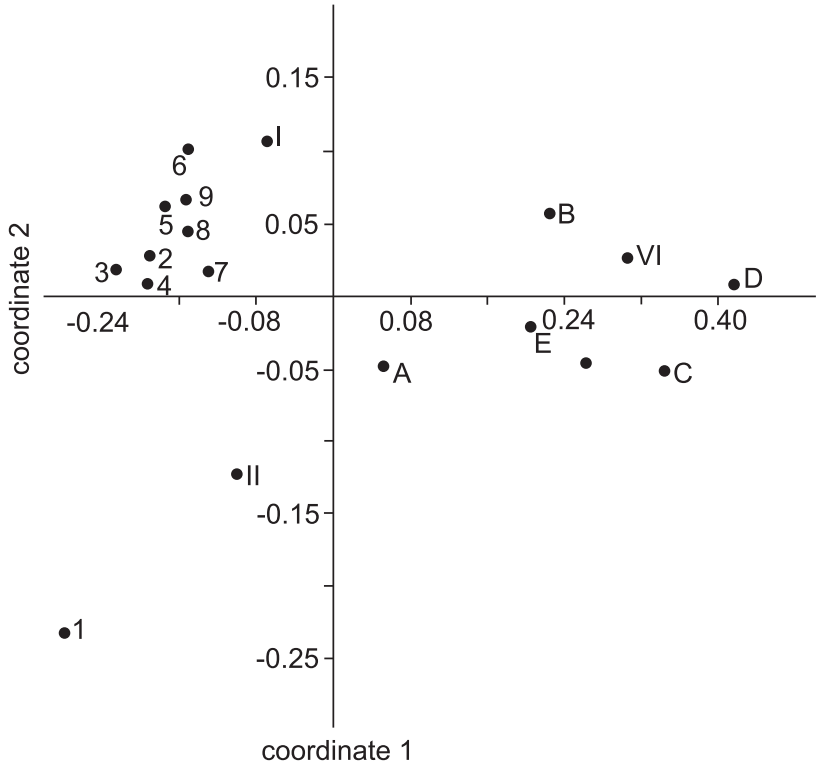

Figure 2. Non-metric multi-dimensional scaling analysis of the sampling stations (SS III, SS IV and SS 10 are excluded) based on environmental data. See Table I for sampling station labels.

Table I. Sampling stations. * Presence of Limnoperna fortunei.

\begin{tabular}{|c|c|c|c|}
\hline & Sampling stations & Geographical coordinates & Sampling dates \\
\hline \multicolumn{4}{|c|}{ Uruguay river } \\
\hline 1 & Moconá Falls & $27^{\circ} 04^{\prime} \mathrm{S}, 53^{\circ} 53^{\prime} \mathrm{W}$ & 02/III/2006 \\
\hline 3 & San Javier & $27^{\circ} 52^{\prime} \mathrm{S}, 55^{\circ} 08^{\prime} \mathrm{W}$ & $02 / I I I / 2006$ \\
\hline 4 & Garruchos & $28^{\circ} 10^{\prime} \mathrm{S}, 55^{\circ} 38^{\prime} \mathrm{W}$ & $01 / \mathrm{III} / 2006$ \\
\hline 5 & Santo Tomé & $28^{\circ} 33^{\prime} 47^{\prime \prime} \mathrm{S}, 56^{\circ} 01^{\prime} 04^{\prime \prime} \mathrm{W}$ & $01 / \mathrm{III} / 2006$ \\
\hline 6 & Yapeyú & $29^{\circ} 28^{\prime} 32^{\prime \prime} \mathrm{S}, 56^{\circ} 48^{\prime} 53^{\prime \prime} \mathrm{W}$ & $01 / \mathrm{III} / 2006$ \\
\hline 7 & Paso de los Libres & $29^{\circ} 43^{\prime} 22^{\prime \prime} \mathrm{S}, 57^{\circ} 04^{\prime} 57^{\prime \prime} \mathrm{W}$ & 28/II/2006 \\
\hline 8 & Bonpland & $29^{\circ} 58^{\prime} 47^{\prime \prime} \mathrm{S}, 57^{\circ} 20^{\prime} 11^{\prime \prime} \mathrm{W}$ & $28 / 11 / 2006$ \\
\hline \multirow[t]{3}{*}{$9^{*}$} & Monte Caseros & $30^{\circ} 16^{\prime} \mathrm{S}, 57^{\circ} 39^{\prime} \mathrm{W}$ & a) $27 / 11 / 2006$, \\
\hline & & & b) $07 / \mathrm{XI} / 2006$ \\
\hline & & & c) $18 / \mathrm{V} / 2009$ \\
\hline $10^{*}$ & Miriñay river mouth & $30^{\circ} 10^{\prime} 11^{\prime \prime} \mathrm{S}, 57^{\circ} 7^{\prime} 58^{\prime \prime} \mathrm{W}$ & $10 / I I / 2007$ \\
\hline A & Miriñay river, Paso Rosario & $29^{\circ} 33^{\prime} 44^{\prime \prime} \mathrm{S}, 57^{\circ} 30^{\prime} 34^{\prime \prime} \mathrm{W}$ & $28 / 11 / 2006$ \\
\hline B & Miriñay river, Paso Ledesma & $29^{\circ} 50^{\prime} 47^{\prime \prime} \mathrm{S}, 57^{\circ} 40^{\prime} 24^{\prime \prime} \mathrm{W}$ & $28 / 11 / 2006$ \\
\hline C & Pay Ubre Grande brook & $29^{\circ} 01^{\prime} 44^{\prime \prime} \mathrm{S}, 58^{\circ} 10^{\prime} 27^{\prime \prime} \mathrm{W}$ & 03/III/2006 \\
\hline $\mathrm{D}$ & Corriente river & $28^{\circ} 59^{\prime} 45^{\prime \prime} \mathrm{S}, 58^{\circ} 33^{\prime} 30^{\prime \prime} \mathrm{W}$ & 03/III/2006 \\
\hline $\mathrm{E}$ & Santa Lucía river & $28^{\circ} 46^{\prime \prime} \mathrm{S}, 58^{\circ} 57^{\prime} 26^{\prime \prime} \mathrm{W}$ & 03/III/2006 \\
\hline \multicolumn{4}{|c|}{ Argentine tributaries of the Uruguay river } \\
\hline $\mathrm{I}$ & Pepirí Guazú river & $26^{\circ} 36^{\prime} \mathrm{S}, 53^{\circ} 44^{\prime} \mathrm{W}$ & $02 / I I I / 2006$ \\
\hline II & Yabotí river & $27^{\circ} 09^{\prime} \mathrm{S}, 53^{\circ} 55^{\prime} \mathrm{W}$ & $02 / I I I / 2006$ \\
\hline III & López Guerrero brook & $27^{\circ} 47^{\prime} 55^{\prime \prime} \mathrm{S}, 55^{\circ} 08^{\prime} 31^{\prime \prime} \mathrm{W}$ & $01 / I I I / 2006$ \\
\hline IV & Itacaruaré brook & $27^{\circ} 52^{\prime} 18^{\prime \prime} \mathrm{S}, 55^{\circ} 16^{\prime} 38^{\prime \prime} \mathrm{W}$ & $01 / \mathrm{III} / 2006$ \\
\hline V & Mocoretá river & $30^{\circ} 37^{\prime} 40^{\prime \prime} \mathrm{S}, 57^{\circ} 59^{\prime} 01^{\prime \prime} \mathrm{W}$ & $27 / I I I / 2006$ \\
\hline $\mathrm{VI}$ & Gualeguay river & $30^{\circ} 36^{\prime} \mathrm{S}, 33^{\circ} 18^{\prime} \mathrm{W}$ & $27 / 11 / 2006$ \\
\hline
\end{tabular}


Limnoperna fortunei was found at two sampling stations, i.e., Monte Caseros (SS 9) and the mouth of the Miriñay River (SS 10), both sites located on the right bank of the Uruguay River. In 2006, adults and larvae of $L$. fortunei were detected in SS 9; on 18 May 2009 a density of $1,517.78$ ind $\mathrm{m}^{-2}$ was recorded on rocks and gravel. On 10 February 2007, adults were collected from submerged branches and roots at SS 10, with an average density of 20,389.4 ind. $\mathrm{m}^{-2}$.

Total dissolved salts values recorded fall between 0.0160 to 0.8552 g.L $^{-1}$ (Fig. 3). The $\mathrm{pH}$ range recorded at the sampling localities was 6.0 to 8.8 (Fig. 4, Tabs II, III). Most frequent values were 7.7 to 7.9 . The water velocity ranged from imperceptible on
SS B (Miriñay River) to $4.16 \mathrm{~m} \mathrm{seg}^{-1}$ at SS 1 (Moconá Falls) (Fig. 5, Tabs II, III). The majority of suspended sediment values (Fig. 6) fall between 0.003 in SS II (Yabotí River) and 0.31 g.L. - $^{-1}$ in SS VI (Gualeguay River). Calcium concentration data were recorded in the Uruguay and Paraná tributaries and in emissaries of the Esteros del Iberá wetland. Fig. 7 shows a wide dispersion of $\mathrm{Ca}^{++}$concentration values. The lowest values of $\mathrm{Ca}^{++}$were recorded at SS8 and SS7 (Paso de los Libres and Bonpland), where concentrations were slightly below $3 \mathrm{mg} . \mathrm{L}^{-1}$. The highest value, above 50 mg. $\mathrm{L}^{-1}$, was recorded at SS C (Pay Ubre Grande brook). Dissolved oxygen concentrations varied between 3.7 and $11.2 \mathrm{mg} \cdot \mathrm{L}^{-1}$ at SS C (Pay Ubre Grande brook) and SS II (Yabotí River) (Fig. 8).
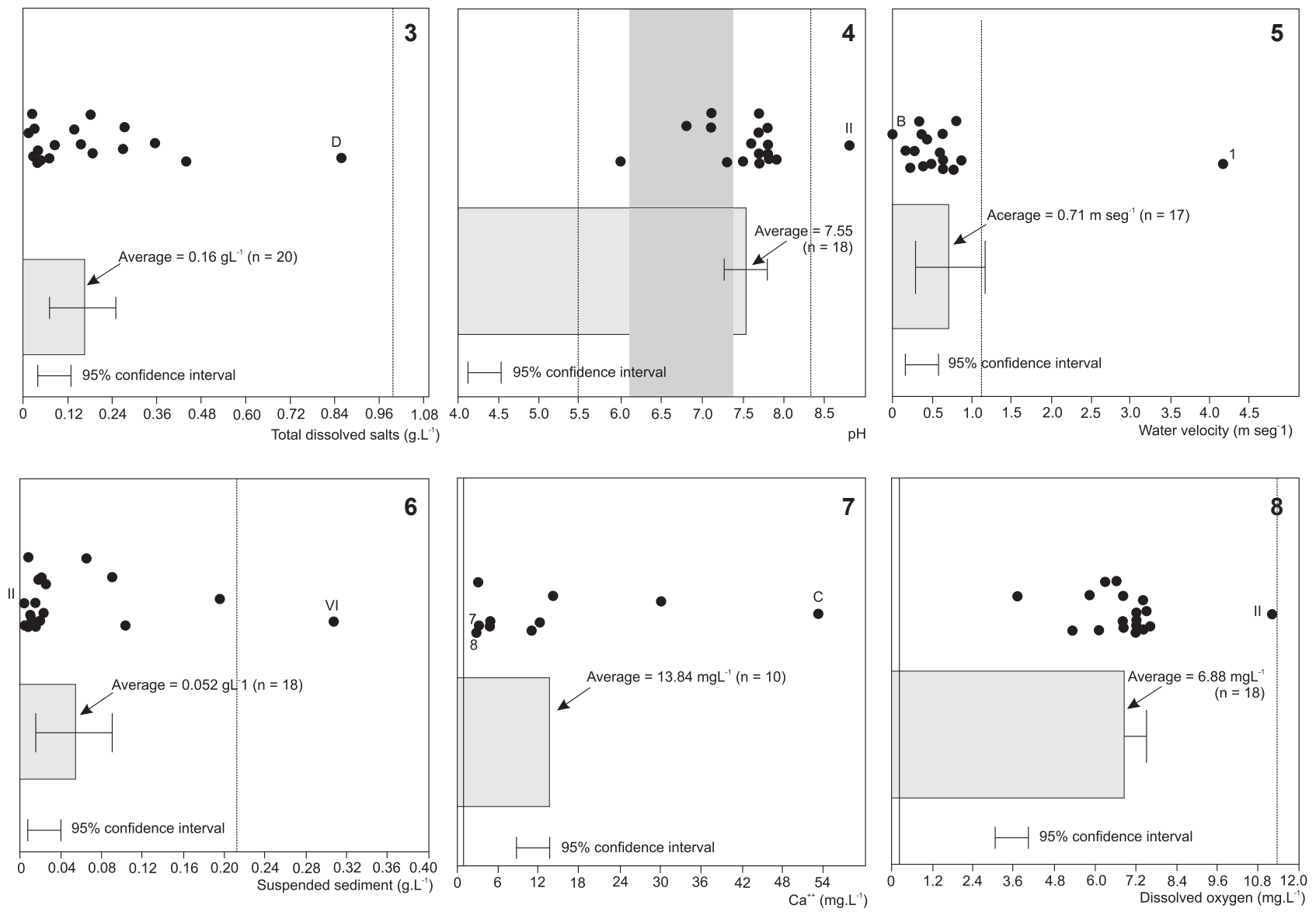

Figures 3-8. Jitter plots of the environmental data recorded at the sampling stations compared graphically with the known tolerance limits of Limnoperna fortunei. Bars indicate the arithmetic mean and the $95 \%$ confidence interval. $n=$ number of samples. (3) Total dissolved salts values, dotted line average tolerance limit after DarRIGRAN (2002); D, Corriente river. (4) Values of pH, grey zone indicates the tolerance range limits after DarRigran (2002), left dotted line tolerance limit after Boltovskor et al. (2006), and right dotted line tolerance limit after VILLAR et al. (1997); II, Yabotí river. (5) Water velocity, dotted line tolerance limit after OliveIRA et al. (2011); 1, Moconá Falls; B, Miriñay river. (6) Suspended sediments, dotted line superior tolerance limit after dos SANTos et al. (2008); II; Yabotí river; VI, Gualeguay river. (7) Dissolved $\mathrm{Ca}^{++}$, dotted line lower tolerance limit after OLIVEIRA et al. (2010); 7, Paso de los Libres; 8, Bonpland; C, Pay Ubre Grande brook. (8) Dissolved oxygen, right dotted line upper tolerance limit after Dos SANTOS et al. (2008) and left dotted line lower after OlivelRa et al. (2006); II, Yabotí river.

ZOOLOGIA 29 (6): 531-539, December, 2012 
Table II. Uruguay river sampling stations. Physical and chemical parameters measured during the field trip in February 2006.

\begin{tabular}{|c|c|c|c|c|c|c|c|c|c|}
\hline & 1 & 2 & 3 & 4 & 5 & 6 & 7 & 8 & 9 \\
\hline Parameter & $\begin{array}{l}\text { Moconá } \\
\text { Falls }\end{array}$ & $\begin{array}{l}\text { Alba } \\
\text { Posse }\end{array}$ & San Javier & Garruchos & $\begin{array}{l}\text { Santo } \\
\text { Tomé }\end{array}$ & Yapeyú & $\begin{array}{c}\text { Paso de Los } \\
\text { Libres }\end{array}$ & Bonpland & $\begin{array}{l}\text { Monte } \\
\text { Caseros }\end{array}$ \\
\hline Water velocity $\left(\mathrm{m} . \mathrm{s}^{-1}\right)$ & 4.16 & 0.80 & 0.75 & 0.86 & 0.48 & 0.26 & 0.42 & 0.63 & 0.36 \\
\hline Air temperature $\left({ }^{\circ} \mathrm{C}\right)$ & 31.0 & 31.5 & 38.5 & 31.5 & 35.5 & 31.5 & 31.0 & 26.5 & 29.0 \\
\hline Water temperature $\left({ }^{\circ} \mathrm{C}\right)$ & 30.8 & 30.4 & 32.4 & 32.4 & 32.6 & 29.3 & 31.3 & 28.0 & 28.1 \\
\hline Depth (m) & 1.30 & 1.30 & 1.10 & 1.15 & 1.50 & 1.50 & 0.90 & 1.50 & 1.50 \\
\hline Transparency (m) & bed & bed & bed & bed & 1.36 & bed & bed & 1.19 & 1.05 \\
\hline Suspended sediment $\left(\mathrm{g} \cdot \mathrm{L}^{-1}\right)$ & 0.0184 & 0.0072 & 0.0102 & 0.0220 & 0.0121 & 0.0150 & 0.0241 & 0.0086 & 0.0200 \\
\hline Suspended organic matter $\left(\mathrm{g} \cdot \mathrm{L}^{-1}\right)$ & 0.0022 & 0.0011 & 0.0017 & 0.0029 & 0.0015 & 0.0018 & 0.0011 & 0.0006 & 0.0023 \\
\hline Conductivity $\left(\mu \mathrm{S} . \mathrm{cm}^{-1}\right)$ & 51.0 & 50.0 & 44.0 & 49.0 & 56.2 & 54.0 & 60.0 & 50.0 & 50.0 \\
\hline Total dissolved salts $\left(\mathrm{g} \cdot \mathrm{L}^{-1}\right)$ & 0.0292 & 0.0210 & 0.0388 & 0.0392 & 0.0342 & 0.1556 & 0.0160 & 0.1868 & 0.0292 \\
\hline Dissolved organic matter $\left(\mathrm{g} \cdot \mathrm{L}^{-1}\right)$ & 0.0058 & 0.0118 & 0.0118 & 0.0160 & 0.0112 & 0.1354 & 0.0052 & 0.1086 & 0.0036 \\
\hline Dissolved oxygen $\left(\mathrm{mg} \cdot \mathrm{L}^{-1}\right)$ & 7.6 & 6.6 & 7.2 & 7.2 & 7.2 & 7.2 & 7.4 & 6.8 & 6.8 \\
\hline $\mathrm{pH}$ & 7.8 & 7.7 & 7.7 & 7.8 & 7.8 & 7.8 & 7.7 & 7.7 & 7.1 \\
\hline Dissolved $\mathrm{Ca}^{++}\left(\mathrm{mg} \cdot \mathrm{L}^{-1}\right)$ & - & - & - & - & - & 3.1 & 2.9 & 2.8 & - \\
\hline
\end{tabular}

Table III. Emissaries of the Esteros del Iberá wetland (samples A-E) and argentine tributaries of Uruguay and Paraná rivers (samples I-VI) sampling stations. Physical and chemical parameters measured during the field trip in February 2006.

\begin{tabular}{|c|c|c|c|c|c|c|c|c|c|c|c|}
\hline & $A$ & B & $\mathrm{C}$ & $\mathrm{D}$ & $\mathrm{E}$ & 1 & II & III & IV & V & $\mathrm{VI}$ \\
\hline Parameter & $\begin{array}{l}\text { Miriñay } \\
\text { river Paso } \\
\text { Rosario }\end{array}$ & $\begin{array}{l}\text { Miriñay } \\
\text { river Paso } \\
\text { Ledesma }\end{array}$ & $\begin{array}{c}\text { Pay Ubre } \\
\text { Grande } \\
\text { brook }\end{array}$ & $\begin{array}{c}\text { Corriente } \\
\text { river }\end{array}$ & $\begin{array}{l}\text { Santa } \\
\text { Lucía } \\
\text { river }\end{array}$ & $\begin{array}{c}\text { Pepirí } \\
\text { Guazú } \\
\text { river }\end{array}$ & $\begin{array}{c}\text { Yabotí } \\
\text { river }\end{array}$ & $\begin{array}{c}\text { López } \\
\text { Guerrero } \\
\text { brook }\end{array}$ & $\begin{array}{l}\text { Itacaruaré } \\
\text { brook }\end{array}$ & $\begin{array}{c}\text { Mocoretá } \\
\text { river }\end{array}$ & $\begin{array}{c}\text { Gualeguay } \\
\text { river }\end{array}$ \\
\hline Water velocity $\left(\mathrm{m} . \mathrm{s}^{-1}\right)$ & 0.63 & 0 & 0.17 & 0.37 & 0.33 & 0.22 & 0.59 & - & - & 0.63 & 0.37 \\
\hline Air temperature $\left({ }^{\circ} \mathrm{C}\right)$ & 30.0 & 35.0 & 26.5 & 31.0 & 26.0 & 36.5 & 35.5 & - & - & 24.0 & 29.0 \\
\hline Water temperature $\left({ }^{\circ} \mathrm{C}\right)$ & 26.0 & 30.9 & 25.5 & 29.4 & 28.5 & 31.3 & 35.9 & 26.0 & 26.7 & 25.4 & 26.6 \\
\hline Transparency (m) & 0.30 & 0.16 & bed & 0.49 & 0.31 & bed & bed & - & bed & bed & 0.10 \\
\hline Suspended sediment (g. $\left.\mathrm{L}^{-1}\right)$ & 0.0893 & 0.1958 & 0.0182 & 0.0646 & 0.0148 & 0.0036 & 0.0028 & - & - & 0.1034 & 0.3074 \\
\hline Suspended organic matter $\left(\mathrm{g} \cdot \mathrm{L}^{-1}\right)$ & 0.0099 & 0.0282 & 0.0004 & 0.0040 & 0.0001 & 0.0011 & 0.0011 & - & - & 0.0109 & 0.0202 \\
\hline Conductivity $\left(\mu \mathrm{S} . \mathrm{cm}^{-1}\right)$ & 115.0 & 460.0 & 610.0 & 1470.0 & 290.0 & 91.0 & 76.0 & 95.0 & 136.7 & 380.0 & 600.0 \\
\hline Salinity $\left(\mathrm{g} \cdot \mathrm{L}^{-1}\right)$ & 0.1362 & 0.1828 & 0.4398 & 0.8552 & 0.2678 & 0.0452 & 0.0836 & 0.0474 & 0.0685 & 0.2710 & 0.3546 \\
\hline Dissolved organic matter $\left(\mathrm{g} \cdot \mathrm{L}^{-1}\right)$ & 0.0282 & 0.0152 & 0.0292 & 0.1742 & 0.1382 & 0.0166 & 0.0200 & - & - & 0.0194 & 0.0414 \\
\hline $\mathrm{pH}$ & 6.8 & 7.6 & 7.8 & 7.1 & 7.3 & 6.0 & 8.8 & - & - & 7.5 & 7.9 \\
\hline Dissolved $\mathrm{Ca}^{++}\left(\mathrm{mg} \cdot \mathrm{L}^{-1}\right)$ & 4.8 & 4.8 & 53 & 30 & 12 & - & - & - & - & 14 & 11 \\
\hline
\end{tabular}

\section{DISCUSSION}

Analysis of the physical and chemical parameters of the localities sampled along the Uruguay River upstream from Monte Caseros, and of the studied tributary rivers, together with previous information supplied by other authors from other sites (e.g., Darrigran \& Ezcurra de Drago 2000, Darrigran 2002, Boltovskoy et al. 2006, Karatayev et al. 2007, Darrigran \& Damborenea 2006, Darrigran et al. 2011) suggest that most of the studied sites are propitious for the establishment of $L$. fortunei. Most of the values were within the tolerance range of this species and suggest that the upstream expansion of the golden mussel could be beyond Monte Caseros along the Uruguay River and along its main tributaries.

$\mathrm{Ca}^{++}$concentration is one of the most important factors for the growth of freshwater mollusc populations. The minimum $\mathrm{Ca}^{++}$ concentration mentioned in the literature for the growth of populations of golden mussel ranges between $1 \mathrm{mg} . \mathrm{L}^{-1}$ (OuIveira et al. 2010), 3 mg.L.-1 (RicCiaRDi 1998, BoltovsKoy et al. 2006) and 3.96 mg.L $\mathrm{L}^{-1}$ (DARRIGRAN 2002). Although the recorded concentrations in this study are generally low (between 2.8 and $53 \mathrm{mg}^{-\mathrm{L}^{-1}}$; Tabs II and III), they are still enough for growth of populations of this species. 
Total dissolved salts have been mentioned as a limiting environmental factor for the distribution of $L$. fortunei (Darrigran \& Ezcurra de Drago 2000, Brugnoli et al. 2005, Darrigran \& Damborenea 2005, Darrigran et al. 2011). Stable populations of this bivalve, with high densities and reproductive capability, do not tolerate averages above 1 g.L $\mathrm{L}^{-1}$ (DARRIGRAN \& Damborenea 2006). Capitoli \& Bemvenuti (2004), Capitoli et al. (2008) and Deaton et al. (1989) pointed out that the golden mussel tolerates values lower than 3 g. $\mathrm{L}^{-1}$ and total dissolved salts shocks lower than 2 g. $\mathrm{L}^{-1}$ under experimental conditions (AgONESI et al. 2008). During this study, no sampling station showed concentrations higher than that tolerated by the golden mussel. Therefore, this is not a limiting factor for the growth of populations of $L$. fortunei in this area.

Once the golden mussel is a filtering bivalve, high suspended sediment concentrations make feeding difficult (PEstanA et al. 2009, Darrigran et al. 2011). Concentration of suspended sediment in the areas of the Plata Basin already invaded by this mussel show a maximum concentration of 0.214 g.L.- (DOS SANTOS et al. 2008), values below this were reported in this study, with the exception of the value recorded for the Gualeguay River $\left(0.3014\right.$ g.L $\left.\mathrm{L}^{-1}\right)$.

DARRIGRAN (2002) indicated that Limnoperna fortunei tolerates environments with a wide range of $\mathrm{pH}$ conditions (e.g., 6.27.4). Boltovskoy et al. (2006) mentioned a $\mathrm{pH}$ of 5.5 as the minimum tolerance value. The maximum $\mathrm{pH}$ value at which golden mussels are recorded are 7.8 (Oliveira et al. 2010) and 8.3 (VilLar et al. 1997). Among the studied sampling stations, only one locality (Yabotí River) exhibited a pH of 8.8, which could be limiting factor to the invasion by the "golden mussel".

Another factor that possibly could act as a physical barrier to dispersion of this bivalve is the water velocity in the Uruguay River, at Moconá Falls. During low water periods, the velocity measured was 3.3 to $5 \mathrm{~m} . \mathrm{s}^{-1}$. According to OliveIra et al. (2011), these values are too high for the bivalve to adhere to the substrate. However, settling of this species in the Moconá Falls is possible in certain microhabitats protected from strong currents. In this case, human vectors originate a jump dispersal pattern (Boltovskoy et al. 2006).

Not all the rivers and streams of the Plata Basin already invaded by the golden mussel show rocky outcrops. Some of them are devoid of this kind of substrate, such as the secondary tributaries of the alluvial plain of the middle Paraná River (Darrigran \& Ezcurra de Drago 2000) and also along the lower Paraguay River (EzcurRa de Drago et al. 2004). L. fortunei can also grow along sectors of the riverbed with consolidated clayish sediments or on gravel with pebbles of up to $10 \mathrm{~mm}$ diameter. One attached specimen is enough to be used subsequently by other juveniles as substrate (ItUARTE 1997) until the pebble reaches a tennis-ball size conglomerate. On the other hand, the settling of juvenile and/or adult specimens of $L$. fortunei on roots of floating or terrestrial riparian vegetation (MANsur et al. 2003, MarÇAL \& CALliL 2008) - or on any other kind of hard substrate - has been mentioned by several authors before (DARRIGRAN \& DAMBORENEA 2006). In environments such as those found in the alluvial plain of the middle Paraná River, $L$. fortunei competes for space with several species of sponges living in the periphyton. In the Uruguay River - in the Salto Grande reservoir -, Ezcurra de Drago (2004) observed the exuberant growth of $L$. fortunei on the sponge Trochospongilla repens (Hinde, 1888). This author pointed out to the stiffness and rugosity of certain species of sponges of the Neotropical region, resulting in an appropriate substrate for $L$. fortunei when compared with other types of available substrates. This differs from observations on D. polymorpha, in which the fragility of all the sponge species from the Holartic Region - as already demonstrated in the field and laboratory (Ricciardi et al. 1995) - hinders the settlement of the bivalve on these organisms.

From the above-mentioned discussion it derives that all the sampled sites (except Moconá Falls and Yabotí River) are appropriate for the establishment of populations of $L$. fortunei. Likewise, dispersion of this species in America depends mainly of humans acting as dispersion vectors (DARRIGRAN 2002). An example of this is the presence of the golden mussel in Monte Caseros, immediately upstream of the northernmost reaches of the Salto Grande reservoir (Fig. 1). This can be due to two factors: I) flooding of the reservoir during high hydrometric levels of the Uruguay River, facilitating transport and distribution upstream of the larvae of $L$. fortunei, and II) fluvial-maritime large-vessel traffic up to the city of Concepción del Uruguay $\left(32^{\circ} 29^{\prime} \mathrm{S}, 58^{\circ} 14^{\prime} \mathrm{W}\right)$ and of smaller boats up to Concordia $\left(31^{\circ} 23^{\prime} \mathrm{S}, 58^{\circ} 01^{\prime} \mathrm{W}\right)$, which have been an invasion vector for this bivalve (DARRIGRAN \& ARCARIA 2011). These two factors and the practice of water sports and fishing in the Salto Grande reservoir have been crucial in the dispersion of this species. In this sense, the emissaries of the Iberá Wetlands (Fig. 1) could act as dispersion paths of the golden mussel into those systems as well as out of them. This suggests that, as a consequence of human activities, the invasion of $L$. fortunei into the Iberá Swamps is only a question of time. So far, the presence of the "golden mussel" has not been detected in the middle courses of the Corriente and Santa Lucía rivers, both of which drain the Iberá Swamps and other associated wetlands into the Paraná River. Possibly, the non-navigability of these rivers is one of the main factors retarding the invasion. However, increased tourism and fishing during the past few years will probably facilitate the dispersion. These swamps, together with the Pantanal Wetland, are the largest hydrosystems in southern South America. Therefore, it becomes imperative to continue research on this invading bivalve. Authorities should be alert and enforce adequate legislation concerning the entrance of vessels into these environments in order to prevent invasion by adults attached to them or by moving containers with water that may contain larvae.

Limnologic parameters of the Esteros del Iberá Wetland are different from other freshwater environments of the Paraná 
Basin, probably due to the pluvial origin of the water and the widespread presence of clean sands with little calcareous materials and other minerals. All aquatic environments in this system have little minerals in solution (18.2-58.6 mg. $\left.\mathrm{L}^{-1}\right)$, and hence low conductivity (CAsciotTa et al. 2005). The pH is highly fluctuating due to the scarcity of buffer agents like carbonates and bicarbonates, and follows carbon dioxide fluctuations originated in the activity of organisms (photosynthesis and respiration).Calciumcarbonaterarelyreachesvaluesabove $20 \mathrm{mg}^{\mathrm{L}} \mathrm{L}^{-1}$, theminimumvalueto support a normal aquatic biota (BAIN \& STEVENSON 1999, CASCIOTTA et al. 2005). Nutrient levels are very low (N-NO3 between 0.015 and $0.194 \mathrm{mg} . \mathrm{L}^{-1} ; \mathrm{P}-\mathrm{PO} 4$ between 0.009 and $0.085 \mathrm{mg} . \mathrm{L}^{-1}$ ) (Lancelle 2003, Casciotta et al. 2005). On the basis of these characteristics, Limnoperna fortunei should have some barriers to the development of stable and dense populations in the system. However, considering that the invasion began during the late 1990s in the Pantanal (DARRigran \& DAMBorenea 2006), and that the Iberá wetland is a large area with many different environmental conditions, it seems likely that the golden mussel will eventually invade the system. The unique features of the Estereos del Iberá suggest that the introduction and settlement of any invading species could cause significant damage to the stability of the system. Because the golden mussel is considered an ecosystem engineer, environmental impact would probably be high (DARRigran \& DAMBORENEA 2011).

According to Callil (2008), L. fortunei follows, in South America, the same invasion pattern followed before by Corbicula fluminea (Müller, 1774), stressing the coincidence of the dispersion of $C$. fluminea since the late 1970s with the dispersion of $L$. fortunei since its introduction on 1991. C. fluminea is common in the benthos of the Uruguay River (DARRIGRAN 2002). So, after Kluza \& MCNyset (2005), the knowledge of the invasion pattern of these species would help to the future control of the bioinvasions in South America.

Tools for the prevention of the introduction and establishment of invasive species include risk assessment, early detection and rapid response, and public education (NISC 2001, ELI 2002). Public education is crucial to render sustainable the management of a biological invasion. Social awareness of bioinvasions must be generated. Society must impel, through demands to its government, the application of necessary mechanisms for the prevention of bioinvasions. This awareness can only be achieved with education (DARRIGRAN et al. 2008).

\section{ACKNOWLEDGEMENTS}

The work was founded by Committee Research and Exploration-National Geographic Society (Darrigran, G; Grant 7824-05) by the project "Bioinvasion in the American continent: predicting freshwater bivalve invaders", as well as by FCNyM (UNLP) and CONICET (PIP 1017). We thank M. Lagreca (CIC, Bs. As.) for technical support and INALI (CONICET-UNL) for logistic field support.

\section{LITERATURE CITED}

Angonesi L.G.; N.G. Rosa \& C.E. Da Bemvenuti. 2008. Tolerance to salinities shocks of the invasive mussel Limnoperma fortunei under experimental conditions. Iheringia, Série Zoologia, 98: 66-99.

Agudo-Padrón, A. 2008. Vulnerabilidade da rede hidrográfica do estado de Santa Catarina, ante o avanço invasor do mexilhão-dourado, Limnoperna fortunei (Dunker, 1857). Revista Discente Expressões Geográficas, Florianópolis 4: 75103.

Agudo-padrón, A. I.; É. Porto filho \& K. SaAlfeld. 2012. First confirmed record of Limnoperna fortunei (Dunker, 1857) in Santa Catarina State, Southern Brazil. Rio de Janeiro, RJ, In: XI International Congress on Medical and Applied Malacology.

Bain, M. \& N. Stevenson. 1999. Aquatic habitat assessment. Common methods. Maryland, American Fisheries Society, $136 \mathrm{p}$.

Boltovskoy, D.; N. Correa; D. Cataldo \& F. Sylvester. 2006. Dispersion and ecological impact of the invasive freshwater bivalve Limnoperna fortunei in the Río de la Plata watershed and beyond. Biological Invasions 8: 947-963.

Bonetto, A. \& H. Hurtado. 1998. Sistema del Iberá, p. 31-72. In: P. Canevari; D. Blanco; C. Bucher; G. Castro \& I. Davidson (Eds). Los humedales de la Argentina. Buenos Aires, Wetlands International Publ., 208p.

Brugnoli, E.; J. Clemente; L. Boccardi; A. Borthagaray \& F. SCARABINO. 2005. Golden mussel Limnoperna fortunei (Bivalvia: Mytilidae) distribution in the main hydrographical basins of Uruguay: update and predictions. Anais da Academia Brasileira de Ciências 77: 235-244.

Brugnoli, E.; P. Muniz; N. Venturini \& L. Burone. 2007. Environmental Perturbation and Coastal Benthic Biodiversity in Uruguay, p. 6-57. In: I.C. WILLIS (Ed.). Progress in Environmental Research. New York, Nova Publishers, 628p.

CALLIL, C. 2008. Cronologia da invasão, novos registros de ocorrência e traços populacionais de corbicilidae na América do sul: um rastro para a dispersão do mexilhão dourado? In: VII Congreso Latinoamericano de Malacología, Simpósio III Moluscos como Bioinvasores 31.

Capítoli, R. \& C. Bemvenuti. 2004. Distribuição do mexilhão dourado Limnoperna fortunei (Dunker, 1857) na área estuarina da Lagoa dos Patos e canal São Gonçalo. In: Simpósio de Ecossistemas Brasileiros, São José dos Campos, Anais 6.

Capítoli R.R., L.A. Colling \& C.E. Bemvenuti. 2008. Cenários de distribuição do mexilhão dourado Limnoperna fortunei (Mollusca - Bivalvia) sob distintas condições de salinidade no complexo lagunar Patos-Mirim, RS - BRASIL. Atlântica 30: 35-44.

Casciotta, J.; A. Almirón \& J. Bechara. 2005. Peces del Iberá. Hábitat y diversidad. Buenos Aires, Grafikar Ed., 244p. 
Claudi, R. \& G. Mackie. 1994. Practical manual for Zebra Mussel monitoring and control. Toronto, CRC Press, 427p.

Darrigran, G. 2002. Potential impact of filter-feeding invaders on temperate inland freshwater environments. Biological Invasions 4: 145-156.

Darrigran, G. 2010. Summary of the distribution and impact of the golden mussel in Argentina and neighboring countries, p. 389-396. In: R. Claudi \& G. Mackie (Eds). Practical Guide for the Monitoring and Control of Aquatic Invasive Molluscs in Freshwater Systems. Boca Raton, Taylor \& Francis Group, 527p.

Darrigran, G. \& N. Arcaría. 2011. Las invasiones biológicas en la costa Argentina y en la Cuenca del Plata, p. 179192. In: A.R. López \& S.C. Marcomini (Eds). Problemática de los Ambientes Costeros. Sur de Brasil, Uruguay y Argentina. Buenos Aires, UNESCO, Editorial Croquis, 204p.

Darrigran, G. \& C. Damborenea. 2005. A bioinvasion history in South America. Limnoperna fortunei (Dunker, 1857), the golden mussel. American Malacological Bulletin 20: 105112.

Darrigran, G. \& C. Damborenea. 2006. Bio-invasión del mejillón dorado en el continente americano. La Plata, EDULP, 226p.

Darrigran, G. \& C. Damborenea. 2011. Ecosystem engineering impacts of Limnoperna fortunei in South America. Zoological Science 28: 1-7.

Darrigran, G. \& I. Ezcurra de Drago. 2000. Invasión of the exotic freshwater mussel Limnoperna fortunei (Dunker, 1857) (Bivalvia: Mytilidae) in South America. The Nautilus 114: 69-73.

Darrigran, G. \& M.C.D. Mansur. 2006. Distribución, abundancia y dispersión, p. 93-112. In: G. Darrigran, \& C. Damborenea (Eds). Bio-invasión del mejillón dorado en el continente americano. La Plata, EDULP, 226p.

Darrigran, G. \& G. Pastorino. 1995. The Recent Introduction of Asiatic Bivalve, Limnoperna fortunei (Mytilidae) into South America. Veliger 38: 171-175.

Darrigran, G. \& G. Pastorino. 2004. Distribution of the golden mussel Limnoperna fortunei (Dunker, 1857) (Family Myilidae) after 10 years invading America. Journal of Conchology, Special Publication 3: 95-102.

Darrigran, G.; S.M. Martin; B. Gullo \& L. Armendariz. 1998. Macroinvertebrados associated to the byssus of Limnoperna fortunei (Dunker, 1857) (Pelecypoda, Mytilidae). Río de la Plata, Argentina. Hydrobiologia 367: 223-230.

Darrigran, G.; M. Maroñas \& D. ColautTi. 2004. Air exposure as a control mechanism for the "golden mussel" Limnoperna fortunei (Dunker, 1857) (Bivalvia, Mytilidae). Journal of Freshwater Ecology 19: 461-464.

Darrigran, G.; C. Damborenea \& N. Greco. 2007. Freshwater invasive bivalves in man-made environments: A case study of larvae biology of Limnoperna fortunei in a Hydroelectric Power Plant in South America. Ambio 36: 575-579.

Darrigran, G.; A. Vilches. \& T. Legarralde. 2008. Desinterés del Pasado, Decisiones del Futuro: Educación para prevenir las invasiones biológicas. Revista de Educación en Biología 11: $39-52$.

Darrigran, G.; C. Damborenea; E. Drago; I. Ezcurra de Drago \& A. PAira. 2011. Environmental factors restrict the invasion process of Limnoperna fortunei (Mytilidae) in the Neotropical Region: a case study from the Andean tributaries. Annales de Limnologie-International Journal of Limnology 47: 221-229.

Deaton, L.E.; J.G. Derby; N. Subhedar \& M. Greenberg. 1989. Osmoregulation and salinity tolerance in two species of bivalve mollusk: Limnoperna fortunei and Mytilopsis leucophaeta. Journal of Experimental Marine Biology and Ecology 133: 67-79.

dos Santos, C.P.; M.C.D. Mansur \& N.L. Würdig. 2008. Variações no comprimento dos indivíduos de uma população do mexilhão dourado, Limnoperna fortunei (Mollusca: Bivalvia: Mytilidae), ao longo do ano, na Praia do Veludo, Lago Guaíba, Rio Grande do Sul, Brasil. Revista Brasileira de Zoologia 25: 389-396.

ELI. 2002. Halting the Invasion: State Tools for Invasive Species Management. Washington, DC, Environmental Law Institute, 112p.

Ezcurra de Drago, I. 2004. Biodiversidad de Porifera en el Litoral Argentino. Grado de Competencia con el Bivalvo invasor Limnoperna fortunei (Dunker, 1857) (Bivalvia, Mytilidae), p. 195-204. In: F.G. AceÑolazA (Ed.). Temas de la Biodiversidad del Litoral fluvial argentino. INSUGEO, Miscelánea 12, $378 \mathrm{p}$.

Ezcurra de Drago, I.; M. Marchese \& K.M. Wantzen. 2004. Benthos of a large neotropical river: Spatial patterns in Benthic invertebrate community structure along the Lower Paraguay Floodplain System. Archiv für Hydrobiologie 160: 347-374.

Ferrati, R.; G.A. Canzian \& D. Ruiz Moreno. 2005. Esteros del Ibera: hydrometeorological and hydrological characterization. Ecological Modelling 186: 3-15.

Hammer, Ø.; D. Harper \& P. Ryan. 2001. PAST: paleontological statistics software package for education and data analysis. Palaeontologia Electronica 4: 1-9.

Iglesias de Cuello, A. 1981. Atlas Total de la República Argentina. Buenos Aires, Centro Editor de América Latina. 344p.

Ituarte, C. 1997. Limnoperna fortunei (Dunker, 1987) (Bivalvia: Mytilidae) en la costa Uruguay del Río de la Plata. Neotropica 43: 117-118.

Karatayev, A.I.; D.K. Padilla; D. Minchin; D. Boltovskoy \& L.E. Burlakova. 2007. Changes in global economies and trade: the potential spread of exotic freshwater bivalves. Biological Invasions 9: 161-180.

KluzA, D. \& K. McNyset. 2005. Ecological Niche Modeling of Aquatic Invasive Species. Aquatic Invaders 16: 1-7.

LANCELLE, H. 2003. Características físicas y químicas de las aguas del Iberá, p. 12-21. In: A. PoI \& A. NeIfF (Eds). Limnología del Iberá. Aspectos físicos, químicos y biológicos de las 
aguas. Corrientes, Editorial Universitaria del la Universidad Nacional del Nordeste, 191p.

LANGONe, J. 2005. Notas sobre el mejillón dorado Limnoperna fortunei (Dunker, 1857) (Bivalvia, Mytilidae) en Uruguay. Museo Nacional de Historia Natural y Antropología. Publicación Extra 1: 1-17.

Lima, L. Lopez de; E. Querol \& É.V. Oliveira. 2008. Ocorrência de Limnoperna fortunei (Dunker, 1857) (Mollusca, Mytilidae) no Rio Quaraí, Município de Barra do Quaraí, Rio Grande Do Sul, Brasil. Biodiversidade Pampeana Pucrs, Uruguaiana, 6: $50-52$

Mansur, M.C.D.; C. P. dos Santos; G. Darrigran; I. Heydrich; C.T. Callil \& F.R. Cardoso. 2003. Primeros dados quali-quantitativos do mexilhao-dourado, Limnoperna fortunei (Dunker), no Delta do Jacuí, no Lago Guaíba e no Laguna dos Patos, Rio Grande do Sul, Brasil e alguns aspectos de sua invasao no novo ambiente. Revista Brasileira de Zoologia 20: 75-84.

Marçal, S. \& C. Callil. 2008. Structure of invertebrates community associated with Eichhornia crassipes Mart. (SolmsLaubach) after the introduction of Limnoperna fortunei (Dunker, 1857) (Bivalvia, Mytilidae) in the Upper Paraguay River, MT, Brazil. Acta Limnologica Brasiliensis 20: 359371.

Montalto, L. \& I. Ezcurra de Drago. 2003. Tolerance to dessication of an invasive mussel, Limnoperna fortunei (Dunker, 1857) (Bivalvia, Mytilidae), under experimental conditions. Hydrobiologia 498: 161-167.

NISC. 2001. Meeting the invasive Species Challenge: National Invasive Species Management Plan. Washington, D.C., National Invasive Species Council, 74p.

Oliveira, M.; A. Takeda; L. Fernandes de Barros; D. Barbosa \& E. KAWAKAMI DE RESENDE. 2006. Invasion by Limnoperna fortunei (Dunker, 1857) (Bivalvia Mytilidae) of the Pantanal wetland, Brazil. Biological Invasions 8: 97-104.

Oliveira, M.; S. Hamilton \& C. Jacobi. 2010. Forecasting the expansion of the invasive golden mussel Limnoperna fortunei in Brazilian and North American rivers based on its occurrence in the Paraguay River and Pantanal wetland of Brazil. Aquatic Invasions 5: 59-73.

Oliveira, M.; D. Calheiros; C. Jacobi \& S. Hamilton. 2011. Abiotic factors controlling the establishment and abundance of the invasive golden mussel Limnoperna fortunei. Biological Invasions 13: 717-729.

Pastorino, G.; G. Darrigran; S. Martin \& L. Lunaschi. 1993. Limnoperna fortunei (Dunker, 1857) (Mytilidae), nuevo Bivalvo invasor en aguas del Río de la Plata. Neotropica 39: 34.

Pestana, D.; M. Pie; A. Ostrensky; W. Boeger; C. Andreoli; F. Franceschi \& P. Lagos. 2008. Seasonal Variation in Larval Density of Limnoperna fortune (Bivalvia, Mytilidae) in the Iguaçu and Paraná Rivers, in the Region of Foz do Iguaçu, Paraná, Southern Brazil. Brazilian Archives of Biology and Technology 51: 607-612.

Pestana, D.; A. Ostrensky; W. Boeger; C. Andreoli \& M. Pie. 2009. The Effect of Temperature and Body Size on Filtration Rates of Limnoperna Fortunei (Bivalvia, Mytilidae) under laboratory conditions. Brazilian Archives of Biology and Technology 52: 135-144.

RicCiardi, A. 1998. Global range expansion of the Asian mussel Limnoperna fortunei (Mytilidae): Another fouling threat to freshwater systems. Biofouling 13: 97-106.

Ricciardi, A.; D. SNyder \& H. Reiswig. 1995. Lethal and sublethal effects of sponge overgrowth on introduced dreissenid mussels in the Great Lakes. Canadian Journal of Fisheries and Aquatic Sciences 52: 2695-2703.

SARdiÑa, P.; E. Chaves \& M. MarChESE. 2011. Benthic community responses to invasion by the golden mussel, Limnoperna fortunei Dunker: biotic homogenization vs environmental driving forces. Journal of the North American Benthological Society 30: 1009-1023.

Sylvester, F.; J. Dorado; D. Boltovskoy; A. Juárez \& D. Cataldo, 2005. Filtration rates of the invasive pest bivalve Limnoperna fortunei as a function of size and temperature. Hydrobiologia 534: 71-80.

Villar, C.; L. Mercado; A. Rodrigues Capitulo \& C. Bonetto. 1997. Presencia del Molusco invasor Limnoperna fortunei (Dunker, 1857) (Bivalvia: Mytilidae) en el Paraná, Gayana Zoologia 61: 87-96.

Zhan, A.; P.V. Perepelizin; S. Ghabooli; E. Paolucci; F. Sylvester; P. Sardiña; M.E. Cristescu \& H.J. Macisaac. 2012. Scale dependent postestablishment spread and genetic diversity in an invading mollusc in South America. Diversity and Distributions 18: 1042-1055.

Submitted: 18.VI.2012; Accepted: 22.XI.2012.

Editorial responsibility: Adriano S. Melo 